elicited multiple mammary tumours (Table 1). Also it produced no toxic deaths. Unsuckled mothers, subjected to the same treatment, died before tumours could be palpated. Suckled mothers tolerated the carcinogen fairly well and two of six developed tumours. Young, ovariectomized and old, virgin rats had similar mortality-rates. Three rats out of five survivors showed tumours in intact old females. While incidence of tumours was variable, the time for appearance of tumours after 3-MC treatment showed no variation. The only exception was registered for ovariectomized rats, in which induction of tumours was delayed.

Histologically, all observed tumours were recog. nizable as adenocarcinomas. The only variant was observed in the castrated females, the tumours of which exhibited a sclerotic and cystic appearance. Gland atrophy with occasional proliferating areas featured in the mammary tissue of old rats. The mammary glands of young intact and ovariectomized rats displayed epithelial proliferations and atrophy, respectively.

The experiment described shows that intolerance to 3-MC affects ovariectomized young and unmated old females, while surprisingly, the carcinogen was lethal to all the unsuckled mothers, except one. Despite the high mortality, the results suggest that the breast of rats which lactated and that of unbred old rats is less susceptible to $\mathbf{3 - M C}$ mammary cancer induction than that of young unbred or ovariectomized rats. Age or different events in the past reproductive activity of female rats have no influence on the rate of tumour appearance after 3-MC treatment. It seems that mammary epithelium (though atrophic) of old rats retains different reacting capacity to a carcinogenic stimulus (3-MC) in relation to its previous functional activity.

\section{Giuliano Briziarelli}

Vister Research Laboratories,

Casatenovo, Como, Italy.

${ }^{1}$ Huggins, C., Grand, L. C., and Brilliantes, F. P., Nature, 189, 204 (1961).

2 Huggins, C., Briziarelli, G., and Sutton, H., J. Exp. Med., 100, 25

${ }^{5}$ Huggins, C., and Briziarelli, G., O.S. Nat. Acad. Sci., Ann. Meeting,

4 Dao, T. L., and Sunderland, H., J. Nat. Cancer Inst., 23, 567 (1959).

'Dao, T. L., Bock, F. G., and Greiner, M. J., J. Nat. Cancer Inst., 25,991 (1960).

- Marchant, J., Nalure, 18a, 629 (1959).

\section{Amino-Acid Composition of Serum Mucoprotein in Rheumatic Fever}

INTEREST in serum mucoprotein tyrosine levels as one of the most sensitive, albeit non-specific, gauges of the disease process in cases of rheumatic fever suggested the possibility that there might be differences in the amino-acid composition of the serum mucoprotein at a time when serum-levels were significantly elevated.

Mucoproteins from five cases of active rheumatic fever whose mean serum mucoprotein tyrosine level was $14.6(11.9-16 \cdot 1) \mathrm{mgm}$. $/ 100 \mathrm{ml}$. and from three normal children of comparable age and with normal serum mucoprotein tyrosine levels of $3.9(3 \cdot 2-4 \cdot 3)$ mgm./100 ml. were separated from other serum proteins by their solubility in $1.2 M$ perchloric acid. After precipitation with 5 per cent phosphotungstic acid the mucoprotein was washed with ethanol, dissolved in a minimum of $0 \cdot 1 \mathrm{~N}$ sodium hydroxide, and finally hydrolysed in vacuo in $6 \mathrm{~N}$ hydrochloric acid for $22 \mathrm{hr}$. at $110^{\circ} \mathrm{C}$.

Analysis of the acid hydrolysate for amino-acids was carried out on a Beckman/Spinco continuous flow column chromatography apparatus using $150-\mathrm{cm}$. and $50-\mathrm{cm}$. columns with standard buffers and temperatures. The mean of the analyses for normal people and for the rheumatic fever cases are shown in Table 1. To facilitate comparison the results are expressed as moles/mole of alanine.

Table 1

\begin{tabular}{|c|c|c|}
\hline & $\begin{array}{c}\text { Normal } \\
\text { (moles/mole of alanine) }\end{array}$ & $\begin{array}{c}\text { Rheumatic fever } \\
\text { (moles/mole of alanine) }\end{array}$ \\
\hline $\begin{array}{l}\text { Aspartic acid } \\
\text { Threonine } \\
\text { Serine } \\
\text { Glutamic acid } \\
\text { Proline } \\
\text { Glycine } \\
\text { Alanine } \\
\text { Valine } \\
\text { Methionine } \\
\text { isoLeucine } \\
\text { Leucine } \\
\text { Tyrosine } \\
\text { Phenylalanine } \\
\text { Lysine } \\
\text { Histidine } \\
\text { Ammonia } \\
\text { Arginine }\end{array}$ & $\begin{array}{l}1 \cdot 46 \\
1.09 \\
0 \cdot 66 \\
2 \cdot 07 \\
1 \cdot 00 \\
0.91 \\
1 \cdot 00 \\
0 \cdot 87 \\
0 \cdot 16 \\
0.62 \\
1 \cdot 23 \\
0.57 \\
0.72 \\
1 \cdot 19 \\
0.35 \\
3.98 \\
0.57\end{array}$ & $\begin{array}{l}1.66 \\
1 \cdot 25 \\
0 \cdot 82 \\
2 \cdot 20 \\
0 \cdot 87 \\
0.94 \\
1.00 \\
0 \cdot 84 \\
0 \cdot 14 \\
0.71 \\
1 \cdot 34 \\
0 \cdot 66 \\
0 \cdot 76 \\
1 \cdot 15 \\
0 \cdot 35 \\
3 \cdot 32 \\
0.63\end{array}$ \\
\hline
\end{tabular}

Values for tryptophan, glucosamine, and cystine are affected by acid hydrolysis and are not given. The figures suggest no difference in amino-acid composition between serum mucoproteins in health and during acute rheumatic fever.
D. O'BRIEN
C. H. M. WALKER
D. WALKER

Department of Pediatrics,

University of Colorado Medical Center, 4200 East Ninth Avenue, Denver 20.

\section{Effect of Calf Thymus Histone on Rats bearing Transplantable Acute Myeloid Leukremia}

THE bactericidal activity and the cytotoxic effect of basic proteins, protamines and histones have been investigated by different workers. However, the cytostatic effect of histones on tumour cells in vitro ${ }^{1-3}$ and in vivo deserves more attention. Do histones possess a specific growth regulatory activity as was suggested by Zbarskii ${ }^{4}$, are they gene inhibitors as Stedman has outlined in his theory ${ }^{5}$, or is the inhibitory action of histones on tumours due only to their high toxicity in the experimented animals?

According to recent work ${ }^{1}$, histones and protamines as very basic proteins are incorporated rapidly into the cells in vitro. The presence of such positively charged proteins within the cells produces changes in their structure and metabolism, with the resulting destruction of the treated cells.

In an effort to estimate the cytostatic effect of histones, rats bearing acute myeloid leukæmia ${ }^{6}$ were treated with calf thymus histone prepared according to the method described by Butler et al.?.

The acute myeloid leukæmia was transplanted into adult $150 \cdot$ gm. albino rats by intravenous injection of the homogenate from leukæmic rat liver, which was heavily infiltrated with leukæmic leucocytes. Histone was administered in 5 per cent solution in physiological saline in $500 \mathrm{mgm}$. $/ \mathrm{kgm}$. doses. The first 